\title{
QUALITY EVALUATION OF HARDY KIWIFRUIT (ACTINIDIA KOLOMIKTA) USING NON-DESTRUCTIVE AND HOLISTIC RESEARCH METHODS
}

Aurelija PAULAUSKIENE், Institute of Agricultural and Food Sciences, Faculty of Agronomy, Vytautas Magnus University. K. Donelaičio g. 58, LT-44248 Kaunas, Lithuania, aurelija.paulauskiene@ vdu.lt (corresponding author)

Živilė TARASEVIČIENĖ, Institute of Agricultural and Food Sciences, Faculty of Agronomy, Vytautas Magnus University. K. Donelaičio g. 58, LT-44248 Kaunas, Lithuania, zivile.taraseviciene@ vdu.lt

Daiva ŠILEIKIENÉ, Institute of Environment and Ecology, Faculty of Forest Sciences and Ecology, Vytautas Magnus University. K. Donelaičio g. 58, LT-44248 Kaunas, Lithuania, daiva.siliekiene@ vdu.lt

Fresh hardy kiwifruit (Actinidia kolomikta (Maxim. \& Rupr.) Maxim.) possible to store for only two weeks at $0-5^{\circ} \mathrm{C}$, therefore in order to maintain longer, the fruit have to be processed. The purpose of the study was to determine the quality of the Actinidia kolomikta fruit using research methods that are faster and easier, i.e. bioelectric Vincent method and biocrystallization. Four cultivars of Actinidia kolomikta fruits - 'Landè', 'Paukštès Šakarva', 'Laiba' and 'Lankè' - were investigated. Fresh, frozen and freeze-dried fruit were analysed. The amount of dry matter was determined by drying the samples to constant mass at $105^{\circ} \mathrm{C}$, ascorbic acid was determined by titration with 2,6-dichlorphenol-indophenol sodium salt dehydrate. The $\mathrm{pH}$ and redox potential were measured by $781 \mathrm{pH} / \mathrm{Ion} \mathrm{Meter}$, electrical conductivity was measured by conductometer. $\mathrm{P}$ value as combined parameter was calculated according to the formula. Biocrystallization studies were carried out with fresh, frozen and freeze-dried fruits of all cultivars. The images derived from the encoded by sort samples were characterised with respect to the visual strength of form expression and were described by 10 criteria, criteria were evaluated using a 5-point scale. Research results showed that the dry matter and ascorbic acid content of A. kolomikta fruit significantly depended on the cultivar. Dry matter content of frozen fruit decreased from 4 to $7 \%$, but increased during freezedrying process by 6 to 7 times compare to the fresh fruit. Fruit processing methods increased $\mathrm{pH}$, redox potential and $\mathrm{P}$ values. The lowest redox potential and $\mathrm{P}$ values were determined for fresh fruit, medium for freeze-dried and the highest for frozen fruit samples.

Keywords: ascorbic acid, biocrystallization, elektrochemical parameters.

\section{INTRODUCTION}

Hardy kiwifruit Actinidia kolomikta (Maxim. \& Rupr.) Maxim. are evaluated as a healthy fruit because of high content of biologically active substances. A. kolomikta fruit of different cultivars accumulate large amounts of vitamin $\mathrm{C}$ that varies from 2423 to $11460 \mathrm{mg} \mathrm{kg}^{-1}$ (Pranckietis et al., 2009; Paulauskiene et al., 2013). The ripe fruits fall down; therefore, all fruits are harvested at the same time, when most of them are unripe. Paulauskiene et al. (2013) previous studies have indicated that the greatest amounts of vitamin $\mathrm{C}$ are found in the unripe A. kolomikta fruit.

Fresh $A$. kolomikta fruit possible to store for only $10-14$ days at $0-5^{\circ} \mathrm{C}$, therefore in order to maintain longer, the fruit have to be processed.

The oldest and most frequently used method of preservation is food freezing, which preserves foods taste, texture, and nutritional value better compared to other methods. In low temperatures microorganisms cannot multiply, chemical reactions decreases, and cells metabolic reactions delayes (Delgado, Sun, 2000). The bioactive compounds of frozen products are better protected than using other storage methods (Tosun, Yucecan, 2008). Freeze-drying is treated as one of the most progressive methods for drying high-value products because shrinkage is avoided and produces materials with superior flavour, aroma, colour retention and unchanged nutrition quality (Oikonomopoulou et al., 2011). The nutrient content is reduced only during the sublimation process when the water from the products evaporates. Oikonomopoulou et al. (2011) states, that $98 \%$ of all nutrients in freeze-dried products uphold. Another advantage, that low water activity virtually removes microbiological hazards.

Fruit quality is usually determined by its chemical composition and some physical characteristics. Conventional methods used by researches are often complicated, require expensive reagents, equipment and are prolonged. Therefore, researchers are looking for faster and easier methods to determine fruit quality. According to Bloksma et al. (2001), Bioelectric Vincent method is one of the promising novel fruit quality assessment methods, which provide more knowledge about metabolism and physiological processes. Gajewski et al. (2007) states that life processes in plants can be described as chains of electro-chemical or redox reactions gain from the activity of electrons. Three basic factors: $\mathrm{pH}$, redox potential ( $\mathrm{rH}$ in $\mathrm{mV}$ ) and resistivity ( $\mathrm{R}$ in $\Omega$ ), make up the basis of the method, which translated into P-value an electrochemical parameter of product quality (Kappert, Meltsch, 2007). According to Bioelectric Vincent method, better fresh or processed product

Copyright (C) 2019 The Authors. Published by Vytautas Magnus University. This is an open-access article distributed under the terms of the Creative Commons Attribution License (CC BY 4.0), which permits unrestricted use, distribution, and reproduction in any medium, provided the original author and source are credited. 
quality is attained by a low redox potential and P-value, but a higher resistivity (Wolf, Rey, 1997). Bioelectric Vincent method has been used for the quality assessment of a few fruits and vegetables and found effective including apples, oranges, strawberries, pumpkins, carrots, and tomatoes (Ergun, Jezik, 2011). Collection of biocrystallization data have motivate this method as a useful scientific research for food quality analysis. This holistic method is based on the chemical and physical reaction of food ingredients with a solution of copper chloride $\left(\mathrm{CuCl}_{2} \cdot 2 \mathrm{H}_{2} \mathrm{O}\right)$ (Fritz et al., 2017). The analysis is performed on glass plates and specific dendritic crystallisation images are obtained. The images form through a self-organization process which is influenced by the ingredients (Kokornaczyk et al. 2011; Busscher et al., 2014) and seams to reflect physiological processes of fruit or vegetables like ripening, decomposition and etc. (Fritz et al. 2011). Laboratory procedures of biocrystallization have been standardized (Busscher et al., 2010; Huber et al., 2010; Kahl et al., 2015). The properties of the pattern or picture can be evaluated by human or using special computer programme (Huber et al., 2010; Szulc et al., 2010; Doesburg, Nierop, 2013). Several scientific researches refer that biocrystallization method is particularly suitable for verifying the authenticity of organic products (Siderer et al., 2005; Szulc et al., 2010). The evaluation of the image is based on (1) comparing the strength of the form expression, measured by the concentration of the sample in the image required to form specific structures of the product in reaction with the copper chloride; and (2) linking samples consisting of understudied images to reference images with varying degrees of maturity or degradation (Fritz et al., 2011; Doesburg et al., 2015).

The purpose of the study was to determine the quality of the Actinidia kolomikta fruit using standard and unconventional research methods.

\section{RESEARCH METHODS}

Fruit of Actinidia kolomikta cultivars 'Laiba', 'Lankè', 'Landè' and 'Paukštès Šakarva' were collected from the experimental orchard $\left(54^{\circ} 53^{\prime} \mathrm{N}, 23^{\circ} 50^{\prime} \mathrm{E}\right)$ of the Aleksandras Stulginskis University in the central region of Lithuania. The fruit were handpicked after 62 days after the most abundant flowering at the beginning of August in 2016 and 2017. The fruit were put into perforated boxes and transported to the laboratory. $1 \mathrm{~kg}$ of fruit of each cultivar was immediately analysed. The fruit in the boxes, 4 x $1.0 \mathrm{~kg}$ for each cultivar, were placed in the freezer (Elcold, Denmark) and frozen at $-34^{\circ} \mathrm{C}$. The fruit were analysed after eight hours of freezing. The fruit for freeze drying were cut in half. Freeze drying of $5 \mathrm{~kg}$ of each cultivar fruit were carried out in a freeze dryer (Sublimator 3x4x5, Zirbus GmbH, Germany). The freezing temperature was $-40^{\circ} \mathrm{C}$ and condenser temperature $-72 \pm 1{ }^{\circ} \mathrm{C}$ with chamber pressure of $10 \mathrm{~Pa}$. Secondary heating was carried up to $25^{\circ} \mathrm{C}$. The freeze drying was completed in 48 hours. The freeze dried fruit were powdered in ultra-centrifugal mill (ZM 200, Retsch GmbH, Germany). The fruit powder samples until analysed were stored in sealed containers.

Fresh, frozen and freeze-dried fruit were analysed. For chemical analysis the whole fresh and unfreeze fruit were homogenised with peels and seeds. The amount of dry matter was determined by drying the samples to constant mass at 105 ${ }^{\circ} \mathrm{C}$, ascorbic acid was determined by titration with 2,6-dichlorphenol-indophenol sodium salt dehydrate (LST ISO 6557-2:2000).

The electrochemical parameters were determined in homogenized fresh and unfreeze fruit samples. Freeze-dried fruit powder mixed with distilled water to homogenize fruit consistency. $\mathrm{pH}$ and redox potential $(\mathrm{rH})$ were measured by $781 \mathrm{pH} / \mathrm{Ion}$ Meter (Metrohm, Switzerland), electrical conductivity (electrical conductivity is the reciprocal of electrical resistivity) - by conductometer inoLab Cond 7310 (WTW, Germany). P value as combined parameter of three mentioned parameters was calculated according to the formula: $P=[29.07(r H-2 p H)]^{2} \cdot r H o^{-1}(\mu \mathrm{W})$, where: $\mathrm{rH}-$ redox potential $(\mathrm{mV}) ; \mathrm{pH}-$ the hydrogen-ion activity; rHo - recalculated specific electrical conductivity $\left(\mu \mathrm{S} \mathrm{cm}^{-1}\right)$ (Meier-Ploeger, Vogtmann, 1991).

For the crystallization method, $2 \mathrm{~g}$ of frozen homogenized fruit and $0.5 \mathrm{~g}$ of freeze-dried fruit powder and $100 \mathrm{ml}$ distilled water were first mixed, extracted $30 \mathrm{~min}$. and then filtered through No. 604 filter paper. Floatglass plates of $2 \mathrm{~mm}$ thickness and a surface area of $10.5 \times 10.5 \mathrm{~cm}$ were used. Plexiglas rings (diameter $=9 \mathrm{~cm}$; height $=1 \mathrm{~cm}$ ) were mounted with paraffin on the glass plates. $7.5 \mathrm{ml}$ of juice mixture, $7.5 \mathrm{ml} 10 \% \mathrm{CuCl}_{2}$ and $15 \mathrm{ml}$ of distilled water were pipetted into the resulting dish and crystallised in a crystallisation chamber $(1.9 \times 1.5 \times 1.3 \mathrm{~m})$ at $30{ }^{\circ} \mathrm{C}$ with $50 \%$ humidity. Three dishes per sample (36 dishes per series) were placed into one chamber. The chamber used was roughly comparable to that described by Kahl (2007), differing in the dimensions and equipment. The images derived from the encoded by sort samples were characterised with respect to the visual strength of form expression by comparing image features between the different fruit cultivar. The images were described by 10 criteria: abundance of branches, central arrangement of branches, branching intensity, regularity of branching, brightness of branching, abundance of branching fill, length of branches (spiral, linear, parabolic), radial density of branches, smoothness of branches. Criteria were evaluated using a 5-point scale: 1 point was given for the weakest visual feature and 5 points was given for the strongest visual feature.

Statistical analysis was carried out with software TIBCO Statistica, version 7 (TIBCO Software, USA). The results were analysed using factorial analysis of variance (ANOVA). Differences between fruit cultivars and processing methods were analysed. The arithmetical means and standard deviations (SD) of the experimental data were calculated. Fisher's least-significant-difference (LSD) test was applied to the experimental results to assess differences between mean values at the significance level of $P<0.05$. Correlation and regression analyses were performed to determine the strength and character of the relationships between variables.

\section{RESULTS AND DISCUSSION}

The accumulation of bioactive components in plants varies depending on cultivar, variety, geographic or meteorological factors, agricultural practices and soil composition. In the case of A. kolomikta fruit, some of the biochemical compounds significantly depend on the cultivar (Paulauskiene et al., 2013). Significant differences were 
observed in the dry matter and ascorbic acid contents of fruit after harvest (Table 1). The greatest amount of dry matter accumulated in 'Laiba' fruit (Table 1). Dry matter contents of frozen fruit were less from 4 to $7 \%$ compare to the fresh fruit. Statistical analysis of data shows significant differences among all cultivars. During the freeze-drying process the dry matter content of fruit increased by 6 to 7 times compare to the fresh fruit.

The greatest amount of ascorbic acid was observed in 'Lande' fruit. Our previous studies indicate that fruit of this cultivar usually accumulate larger amounts of ascorbic acid (Paulauskienè et al., 2015). Delgado and Sun (2000I indicated that amount of ascorbic acid in frozen fruit is most influenced by pre-freezing operations and freezing process basely has no significant effect on vitamin loss. In our case freezing process reduced ascorbic acid content 1.2 times and freezedrying 2.0 times in fruit of all cultivars compare to fresh fruit. A significant positive correlation was observed between ascorbic acid and cultivar $\left(r=0.350, R^{2}=0.123\right)$, but negative correlation was recorded between ascorbic acid and fruit processing method $\left(\mathrm{r}=-0.662, R^{2}=0.438\right)$.

Table 1. Chemical composition of Actinidia kolomikta fruit

\begin{tabular}{lccc}
\hline $\begin{array}{l}\text { Cultivar/ } \\
\text { Fruit processing method }\end{array}$ & Fresh & Frozen & Freeze-dried \\
\hline & & Dry matter \% & $94.11 \pm 0.13^{\mathrm{h}}$ \\
\hline 'Paukštès Šakarva' & $14.56 \pm 0.18^{\mathrm{d}}$ & $13.67 \pm 0.09^{\mathrm{c}}$ & $94.39 \pm 0.05^{\mathrm{h}}$ \\
\hline 'Lankè' & $15.12 \pm 0.24^{\mathrm{e}}$ & $14.56 \pm 0.31^{\mathrm{d}}$ & $93.53 \pm 0.38^{\mathrm{g}}$ \\
\hline 'Landè' & $13.11 \pm 0.35^{\mathrm{b}}$ & $12.18 \pm 0.03^{\mathrm{a}}$ & $94.60 \pm 0.15^{\mathrm{h}}$ \\
\hline 'Laiba' & $15.93 \pm 0.27^{\mathrm{f}}$ & $15.25 \pm 0.12^{\mathrm{e}}$ & $2088.76 \pm 35.82^{\mathrm{f}}$ \\
\hline & & $2417.49 \pm 16.87^{\mathrm{d}}$ & $2260.38 \pm 8.45^{\mathrm{c}}$ \\
\hline 'Paukštės Šakarva' & $2867.49 \pm 2.48^{\mathrm{g}}$ & $2950.94 \pm 28.59^{\mathrm{h}}$ & $2036.26 \pm 8.43^{\mathrm{b}}$ \\
\hline 'Lankè' & $3722.81 \pm 8.87^{\mathrm{j}}$ & $3388.51 \pm 14.42^{\mathrm{i}}$ & $1973.82 \pm 6.93^{\mathrm{a}}$ \\
\hline 'Lande’' & $4049.20 \pm 53.00^{\mathrm{k}}$ & $2055.45 \pm 44.57^{\mathrm{b}}$ & \\
\hline 'Laiba' & $2467.13 \pm 5.45^{\mathrm{e}}$ & & \\
\hline
\end{tabular}

The $\mathrm{pH}$ of A. kolomikta fresh and processed fruit ranged from 2.84 to 3.86 (Table 2). Fruit processing increased $\mathrm{pH}$ values. The $\mathrm{pH}$ of the frozen fruit varied significantly from fresh fruit, but differences between frozen and freezedried fruit were insignificant. According to Gajewski et al. (2007), $\mathrm{pH}$ value indicates the ions acidity level and externalizes energetic aspects of life process. The $\mathrm{pH}$ rise means a loss of fruit vitality (Danilcenko et al., 2005).

The redox potential is of central interest for electrochemical research because it represents the intensity of oxidation-reduction reactions. At $\mathrm{rH}<28,3$ - are reducing systems, that can release electrons to other systems with lower $\mathrm{rH}$; at $\mathrm{rH}>28,3$ - are oxidant systems that can accept electrons from systems with higher $\mathrm{rH}$ (Garban, 2008). The values of redox potential for the tested fruit samples were higher than $28 \mathrm{mV}$, which means the domination of oxidative environment (Table 2). The redox potential for the tested fruit varied from $74.70 \mathrm{mV}$ in fresh 'Laiba' fruit to $139.70 \mathrm{mV}$ in frozen 'Laiba' fruit. The redox potential values of frozen fruit were higher and the lowest values were established for fresh fruit. That mean plant cells can use free enthalpy for their activity, and fresh fruit are more suitable to the human organism (Paulauskiene et al., 2006).

Table 2. Electrochemical characteristic of Actinidia kolomikta fruit

\begin{tabular}{|c|c|c|c|}
\hline \multirow{2}{*}{$\begin{array}{l}\text { Cultivar/ } \\
\text { Fruit processing method }\end{array}$} & Fresh & Frozen & Freeze-dried \\
\hline & \multicolumn{3}{|c|}{$\mathrm{pH}$} \\
\hline 'Paukštès Šakarva' & $3.11 \pm 0.02^{\mathrm{b}}$ & $3.32 \pm 0.02^{\mathrm{e}}$ & $3.32 \pm 0.01^{\mathrm{e}}$ \\
\hline 'Lanke’' & $3.08 \pm 0.06^{b}$ & $3.19 \pm 0.01^{\mathrm{c}}$ & $3.23 \pm 0.02^{\mathrm{d}}$ \\
\hline 'Landè' & $2.84 \pm 0.06^{\mathrm{a}}$ & $3.24 \pm 0.02^{\mathrm{d}}$ & $3.26 \pm 0.01^{\mathrm{d}}$ \\
\hline 'Laiba' & $3.34 \pm 0.07^{\mathrm{e}}$ & $3.65 \pm 0.03^{\mathrm{f}}$ & $3.86 \pm 0.02^{\mathrm{g}}$ \\
\hline \multirow[t]{2}{*}{ mean } & 3.09 & 3.35 & 3.42 \\
\hline & \multicolumn{3}{|c|}{ Redox potential mV } \\
\hline 'Paukštès Šakarva' & $78.40 \pm 4.93^{\mathrm{ab}}$ & $131.10 \pm 2.69^{\mathrm{h}}$ & $82.20 \pm 5.16^{\mathrm{b}}$ \\
\hline 'Lankè' & $90.00 \pm 7.24^{\mathrm{c}}$ & $118.70 \pm 3.09^{\mathrm{e}}$ & $92.30 \pm 6.04^{\mathrm{c}}$ \\
\hline 'Landè' & $105.10 \pm 8.40^{\mathrm{d}}$ & $120.30 \pm 1.89^{\mathrm{ef}}$ & $123.90 \pm 3.38^{\mathrm{g}}$ \\
\hline 'Laiba' & $74.70 \pm 7.80^{\mathrm{a}}$ & $139.70 \pm 3.95^{\mathrm{i}}$ & $89.90 \pm 4.70^{\mathrm{c}}$ \\
\hline \multirow[t]{2}{*}{ mean } & 87.05 & 127.45 & 97.08 \\
\hline & \multicolumn{3}{|c|}{$\mathrm{P}$ value $\mu \mathrm{W}$} \\
\hline 'Paukštès Šakarva' & $14.75 \pm 0.40^{\mathrm{b}}$ & $37.39 \pm 0.45^{1}$ & $20.66 \pm 0.60^{\mathrm{e}}$ \\
\hline 'Lanké' & $17.30 \pm 0.23^{\mathrm{d}}$ & $33.69 \pm 0.53^{j}$ & $22.41 \pm 0.78^{\mathrm{f}}$ \\
\hline 'Landè' & $14.14 \pm 0.17^{\mathrm{a}}$ & $34.68 \pm 0.57 \mathrm{k}$ & $25.35 \pm 0.81^{\mathrm{h}}$ \\
\hline 'Laiba' & $15.53 \pm 0.38^{c}$ & $32.68 \pm 0.39^{\mathrm{i}}$ & $23.65 \pm 0.80^{\mathrm{g}}$ \\
\hline mean & 15.43 & 34.61 & 23.02 \\
\hline
\end{tabular}

P-value is used to define vitality of the organism and energy distribution tendencies (Bloksma et al., 2001). The lowest P-values were determined for fresh fruit, medium for freeze-dried and the highest for frozen fruit samples (Table 2). The P-value of the fresh 'Lande' fruit was the lowest. According to Gajewski et al. (2007), the lower P-value means that product is more suitable as food and there is healthier and nutritious. 
Correlation analysis results shown in Table 3. A weak negative correlation between cultivar and fruit $\mathrm{pH}$ was established (Table 3). It was found, that the processing method influenced fruit electrochemical parameters, and correlated most strongly with fruit $\mathrm{pH}$. The strongest positive correlation was fixed between redox potential and P-value.

Table 3. Correlation coefficients $(P<0.01)$

\begin{tabular}{lccc}
\hline & $\mathrm{pH}$ & $\mathrm{rH}$ & $\mathrm{P}$ \\
\hline Cultivar & $\mathrm{r}=-0.334, \mathrm{R}^{2}=0.112$ & - & - \\
\hline Processing method & $\mathrm{r}=0.525, \mathrm{R}^{2}=0.276$ & $\mathrm{r}=0.189, \mathrm{R}^{2}=0.035$ & $\mathrm{r}=0.384, \mathrm{R}^{2}=0.148$ \\
\hline $\mathrm{P}$ & $\mathrm{r}=0.361, \mathrm{R}^{2}=0.130$ & $\mathrm{r}=0.799, \mathrm{R}^{2}=0.634$ & - \\
\hline $\mathrm{P}$ (fresh fruit) & $\mathrm{r}=0.340, \mathrm{R}^{2}=0.116$ & - & - \\
\hline $\mathrm{P}$ (frozen fruit) & $\mathrm{r}=-0.398, \mathrm{R}^{2}=0.158$ & - & - \\
\hline $\mathrm{P}$ (freeze-dried fruit) & - & $\mathrm{r}=0.788, \mathrm{R}^{2}=0.621$ & - \\
\hline
\end{tabular}

Visual evaluation of crystallization images of fresh, frozen and freeze-dried A. kolomikta fruit were performed primarily by estimating impression of the typical character, which made the whole picture, and then by differentiation the separate morphological features. Crystallization images of fresh fruit are shown in Figure 1.

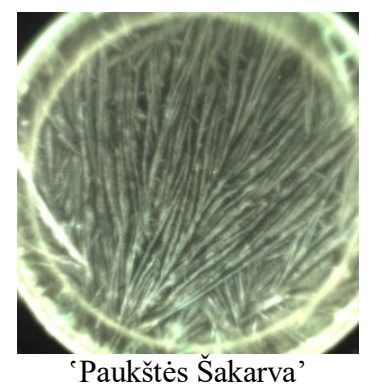

ukštès Sakarva'

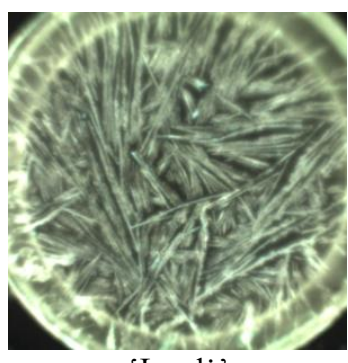

'Landè'

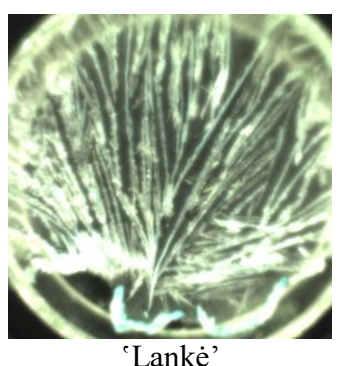

Lanké'

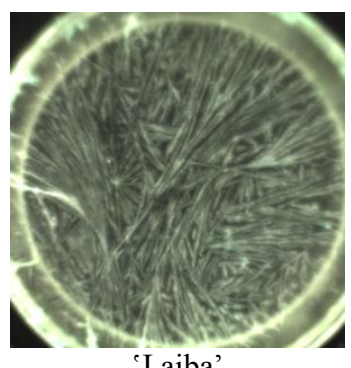

'Laiba'

Figure 1. Actinidia kolomikta fresh fruit crystallograms

All criteria for the crystallization images were evaluated using a 5-point scale and the obtained scores were sum up. Freeze-dried fruit crystallograms were assessed on the highest scores, sum of points ranged from 19.5 for ${ }^{~}$ Paukštės Šakarva' to 36.5 for 'Lankè' (Figure 2). Fresh fruit crystallograms were rated on similar score, and sum of points ranged from 18.5 for 'Lankè' to 34.5 for 'Paukštès Šakarva' fruit. The lowest sum of points was intended for frozen fruit and ranged from 16.5 for 'Lande' to 29.5 for 'Lankè'. This sum characterizes energy value of the product. The higher the value of the product, the more it is suitable for human consumption. The highest value was identified for ${ }^{\mathrm{C}}$ Lankè fruit.

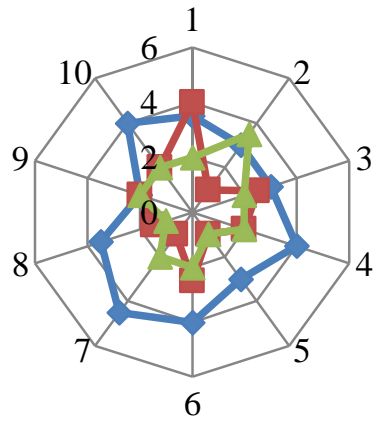

'Paukštès Šakarva'

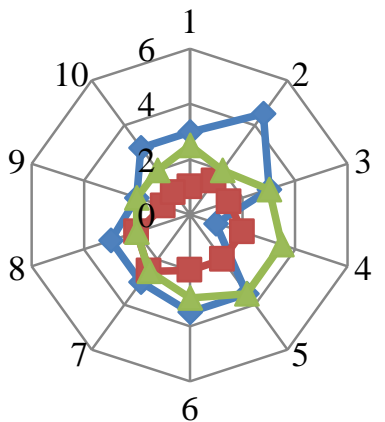

'Landè'

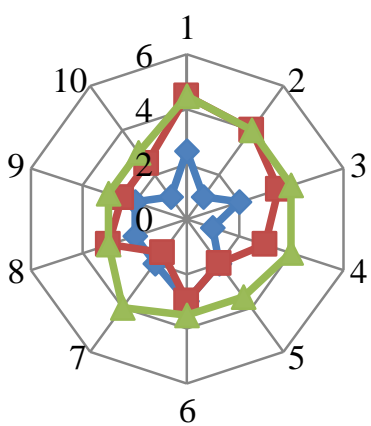

'Lankè'

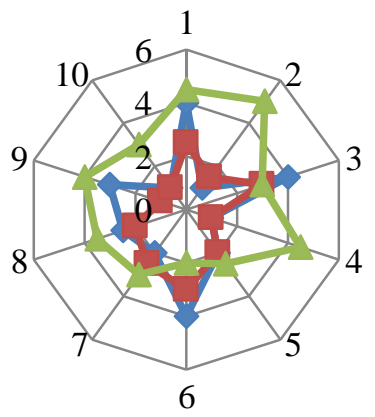

$\sim$ Fresh

- Frozen

$\because$ Freeze-

dried

Figure 2. Scoring for A. kolomikta fruit crystallograms 


\section{CONCLUSIONS}

Dry matter and ascorbic acid content of A. kolomikta fruit significantly depended on the cultivar. Dry matter contents of frozen fruit decreased from 4 to $7 \%$, but increased during freeze-drying process by 6 to 7 times compare to the fresh fruit.

Fruit processing methods increased $\mathrm{pH}$, redox potential and $\mathrm{P}$ values. The lowest redox potential and $\mathrm{P}$-values were determined for fresh fruit, medium for freeze-dried and the highest for frozen fruit samples.

Freeze-dried fruit crystallograms were assessed on the highest scores and on the similar score were rated fresh fruit crystallograms. The results of the crystallograms evaluation confirm the results obtained from the estimation of the electrochemical parameters.

\section{REFERENCES}

1. Bloksma J., Northolt M., Sluber M. 2001. Parameters for apple quality. Louis Bolk Inst., pp. 78-81.

2. Busscher N., Kahl J., Andersen J-O., Huber M., Mergardt G., Doesburg P., Paulsen M., Ploeger A. 2010. Standardization of the biocrystallization method for carrot samples. Biological Agriculture and Horticulture, Vol. 27, pp. 1-23. https://doi.org/10.1080/01448765.2010.10510427

3. Busscher N., Kahl J., Ploeger A. 2014. From needles to pattern in food quality determination. Journal of the Science of Food and Agriculture, Vol. 94, pp. 2578-2581. https://doi.org/10.1002/jsfa.6498

4. Danilcenko H., Paulauskienè A., Rutkovienė V., Kulaitienė J. 2005. The influence of various fertilizers on electrochemical properties of pumpkins fruits. Sodininkystè ir daržininkystè = Horticulture, Vol. 24 (3), pp. 78-86.

5. Delgado A.E., Sun D.W. 2000. Heat and mass transfer for predicting freezing processes, a review. Journal of Food Engineering, Vol. 47, pp. 157-174. https://doi.org/10.1016/S0260-8774(00)00112-6

6. Doesburg P., Huber M., Andersen J-O., Athmann M., van der Bie G., Fritz J., Geier U., Hoekman J., Kahl J., Mergardt G., Busscher N. 2015. Standardization and performance of a visual Gestalt evaluation of biocrystallization patterns reflecting ripening and decomposition processes in food samples. Biological Agriculture and Horticulture, Vol. 31 (2), pp. 128-145. https://doi.org/10.1080/01448765.2014.993705

7. Doesburg P., Nierop A.F. 2013. Development of a structure analysis algorithm on structures from $\mathrm{CuCl} 2 \cdot 2 \mathrm{H} 2 \mathrm{O}$ crystallization with agricultural products. Computers and Electronics in Agriculture, Vol. 90, pp. 63-67. https://doi.org/10.1016/j.compag.2012.11.003

8. Ergun M., Jezik K. 2011. Measuring electrochemical fruit quality of refrigerated 'Hanita' plum by Bioelectric Vincent method. Zemdirbyste-Agriculture, Vol. 98 (3), pp. 315-322.

9. Fritz J., Athmann M., Kautz T., Kopke U. 2011. Grouping and classification of wheat from organic and conventional production systems by combining three image forming methods. Biological Agriculture and Horticulture, Vol. 27, pp. 320-336. https://doi.org/10.1080/01448765.2011.648918

10. Fritz J., Athmann M., Messbner G., Kauer R., Kopke U. 2017. Quality characterisation via image forming methods differentiates grape juice produced from integrated, organic or biodynamic vineyards in the first year after conversion. Biological Agriculture and Horticulture, Vol. 33 (3), pp. 195-213. https://doi.org/10.1080/01448765.2017.1322003

11. Gajewski M., Szymczak P., Elkner K., Dabrowska A., Kret A., Danilcenk, H. 2007. Some aspects of nutritive and biological value of carrot cultivars with orange, yellow and purple-coloured roots. Vegetable Crops Research Bulletin, Vol. 67, pp. 149-161. https://doi.org/10.2478/v10032-007-0039-z

12. Garban Z. 2008. The fundamental problems regarding the relative hydrogen (rH) score in biochemistry. Note I. Theoretical bases of rH determination. Journal of Agroalimentary Processes and Technologies, Vol. 14, pp. 50-57.

13. Huber M., Andersen J-O., Kahl J., Busscher N., Doesburg P., Mergardt G., Kretschmer S., Zalecka A., Meelursarn A., Ploeger A., Nierop D., van de Vijver L., Baars E. 2010. Standardization and validation of the visual evaluation of biocrystallizations. Development of a reliable and valid instrument for visual evaluation according to ISO-Norms for sensory analyses. Biological Agriculture and Horticulture, Vol. 27, pp. 25-40. https://doi.org/10.1080/01448765.2010.10510428

14. Kahl J. 2007. Entwicklung, in-house Validierung und Anwendung des ganzheitlichen Verfahrens Biokristallisation fur die Unterscheidung von Weizen-, Mohren- und Apfelproben aus unterschiedlichem Anbau und Verarbeitungsschritten. Habilitationsschrift, Universitat Kassel; Witzenhausen, Germany.

15. Kahl J., Busscher N., Mergardt G., Andersen J-O., Doesburg P., Arlai A., Ploeger A. 2015. Standardization and performance test of crystallization with additives applied to wheat samples. Food Analytical Methods, Vol. 8 (10), pp. $2533-2540$. https://doi.org/10.1007/s12161-015-0142-6

16. Kappert R., Meltsch B. 2007. Introducing a complementary investigation method concerning fruit and vegetable quality and human health. Acta Horticulturae, Vol. 774, pp. 79-90. https://doi.org/10.17660/ActaHortic.2007.744.7

17. Kokornaczyk M.O., Dinelli G., Marotti I., Benedettelli S., Nani D., Betti L. 2011. Self-organized crystallization patterns from evaporating droplets of common wheat grain leakages as a potential tool for quality analysis. The Scientific World Journal, Vol. 11, pp. 1712-1725. https://doi.org/10.1100/2011/937149

18. LST ISO 6557-2:2000. Vaisiai, daržovès ir jų gaminiai. Askorbo rūgšties kiekio nustatymas. 2dalis. Iprastiniai metodai = Fruits, vegetables and derived products. Determination of ascorbic acid content. Part 2: Routine methods. Lietuvos standartizacijos departamentas, p. 57 [In Lithuanian].

19. Meier - Ploeger A., Vogtmann H. 1991. Lebensmittelqualität - ganzheitliche Methoden und Konzept, 296 p. 
20. Oikonomopoulou V.P., Krokida M.K., Karathanos V.T. 2011. The influence of freeze drying conditions on microstructural changes of food products. Procedia Food Science, Vol. 1, pp. 647-654. https://doi.org/10.1016/j.profoo.2011.09.097

21. Paulauskiene A., Danilcenko H., Jariene E., Gajewski M., Seroczyńska A., Szymczak P., Korzeniewska A. 2006. Quality of pumpkin fruits in relation to electrochemical and antioxidative properties. Vegetable Crops Reseach. Bulletin, Vol. 65, pp. 13-144.

22. Paulauskienè A., Pranckietis V., Barčytė T., Tarasevičienė Ž. 2015. Changes of Actinidia kolomikta fruit texture during storage in controlled atmosphere chambers. Proceedings of $7^{\text {th }}$ international scientific conference "Rural Development 2015", pp. 1-7, Aleksandras Stulginskis University. https://doi.org/10.15544/RD.2015.027

23. Paulauskienė A., Pranckietis V., Tarasevičienė Ž., Barčytė T. 2013. Changes in chemical composition during ripening of Actinidia kolomikta fruits. Proceedings of $6^{\text {th }}$ international scientific conference "Rural Development 2013", Vol. 6, Book 2, pp. 191-194, Aleksandras Stulginskis University.

24. Pranckietis V., Paulauskiene A., Jureviciene V., Taraseviciene Z., Pranckietiene I. 2009. Breeding and processing of Lithuanian cultivars of Actinidia kolomikta (Maxim. and Rupr.) Maxim. fruits grown in organic conditions. Zeszyty Problemowe Postępów Nauk Rolniczych, No. 536, pp. 177-183.

25. Siderer Y., Maquet A., Anklam E. 2005. Needs for research to support consumer confidence in the growing organic food market. Trends in Food Science and Technology, Vol. 16 (8), pp. 332-343. https://doi.org/10.1016/j.tifs.2005.02.001

26. Szulc M., Kahl J., Busscher N., Mergardt G., Doesburg P., Ploeger A. 2010. Discrimination between organically and conventionally grown winter wheat farm pair samples using the copper chloride crystallization method in combination with computerized image analysis. Computers and Electronics in Agriculture, Vol. 74, pp. $218-222$. https://doi.org/10.1016/j.compag.2010.08.001

27. Tosun B.N., Yucecan S. 2008. Influence of commercial freezing and storage on vitamin C content of some vegetables. International Journal of Food Science and Technology, Vol. 43, pp. 316-321. https://doi.org/10.1111/j.1365-2621.2006.01436.x

28. Wolf G., Rey, C. 1997. Wie Qualität elektrochemisch zu messen ist. Vom Lebendigen in Lebensmitteln, ed. M. Hoffmann, Germany, pp. 50-60. 